\title{
Ketersediaan Energi dan Protein Makan Sehari di Pondok Pesantren Al Hikmah Gresik
}

\author{
Yulia Anggraini, Amalia Ruhana \\ Program Studi Gizi, Jurusan Pendidikan Kesejahteraan Keluarga, Fakultas Teknik, \\ Universitas Negeri Surabaya
}

\begin{abstract}
Abstrak
Latar belakang: Pondok pesantren adalah tempat belajar bagi para santri untuk menjadi manusia yang berakhlak baik. Mayoritas santri yang mengikuti pendidikan di pesantren adalah berusia remaja. Remaja merupakan periode penting dalam kehidupan karena terjadi perkembangan fisik, psikologis dan kognitif. Dalam pemenuhan zat gizi, remaja mengalami berbagai masalah pada pola makan maupun keadaan gizinya yang berpengaruh terhadap kesehatannya. Penelitian ini bertujuan untuk mengetahui ketersediaan energi dan protein makan sehari di Pondok Pesantren Al Hikmah Gresik.

Metode: Jenis penelitian adalah penelitian deskriptif dengan pendekatan crossectional study. Lokasi penelitian yaitu Pondok Pesantren Al Hikmah Gresik dengan waktu penelitian bulan oktober-januari 2020. Instrumen pengumpulan data yang digunakan adalah formulir food weighing dengan teknik analisa deskriptif.

Hasil: Dalam penyelenggaraan makanan selama 7 hari diperoleh ketersediaan energi tertinggi sebesar 1766,132 kkal dengan rata-rata sebesar 1408,313 kkal/org/hari (56,68\%). Pada ketersediaan protein selama 7 hari diperoleh ketersediaan tertinggi sebesar 48,899gram dengan rata-rata 40,57 gram/org/hari (64,40\%).

Kesimpulan: Ketersediaan energi dan protein pada Pondok Pesantren Al Hikmah masih dibawah standard ratarata konsumsi di tingkat ketersediaan.
\end{abstract}

Kata kunci: Gizi remaja, Ketersediaan energi, Ketersediaan protein.

\section{The Availlabillity of Energy and Protein for Daily Eating at Al Hikmah Islamic Boarding School Gresik}

\begin{abstract}
Background: an Islamic boarding school is a place of learning for students to become human beings with excellent character. The majority of students who attend Islamic boarding schools are adolescents. Adolescence is a crucial period in life because of physical, psychological, and cognitive development. In fulfilling nutrition, adolescents experience various problems with their diet and nutritional status that impact health. Indeed, this research aims to recognize the availability of energy and protein for daily eating at Islamic Boarding School Al Hikmah Gresik.

Method: This type of research was a descriptive study with a cross-sectional study approach. The research was located at Islamic Boarding School Al Hikmah Gresik. The research was conduct around October-January 2020. The data collection instrument used the food weighing form with descriptive analysis techniques.

Results: The highest energy availability for seven days was obtained at 1766,132 kcal with an average of $1408,313 \mathrm{kcal} /$ person/day $(56,68 \%)$. On the availability of protein for seven days, the highest availability was obtained at 48,899 grams with an average of 40,57 grams/person/day (64,40\%).

Conclusion: The availability of energy and protein at Al Hikmah Islamic Boarding School is still below the average consumption standard at the level of availability.

Keywords: Nutrition for teenagers, Availability of energy, and Availability of protein.
\end{abstract}

Korespondensi: Yulia Anggraini

Email: anggrainiyuliaa@gmail.com 


\section{PENDAHULUAN}

Pondok pesantren merupakan salah satu tempat untuk mendidik santri menjadi manusia yang berakhlak mulia, sehingga sangat penting untuk memperoleh perhatian yang khusus terutama dalam kesehatan dan pertumbuhannya. Selama proses pendidikan, mayoritas santri di pesantren berusia remaja. Remaja merupakan periode penting dalam kehidupan dikarenakan terjadinya perkembangan fisik, psikologis dan kognitif. ${ }^{1}$ Masa remaja juga merupakan masa peralihan dari anak-anak menuju dewasa yang ditandai dengan munculnya berbagai perubahan. Perubahan yang muncul seperti pertambahan massa otot, jaringan lemak tubuh, dan perubahan hormon sehingga terjadi peningkatan kebutuhan gizi. ${ }^{2}$ Kebutuhan zat gizi pada masa remaja lebih banyak dibandingkan dengan pada masa anak-anak karena meningkatnya pertumbuhan dan ukuran tubuh. ${ }^{3}$ Selain itu, remaja laki-laki memiliki kebutuhan zat gizi yang lebih besar daripada remaja perempuan. ${ }^{3}$

Dalam rangka memenuhi kebutuhan zat gizi, remaja mengalami berbagai masalah. Masalah yang muncul adalah seputar kesehatan dan gizi yang berhubungan dengan status gizi maupun yang berhubungan dengan pola makan. Hal ini dapat berdampak pada kesehatan remaja itu sendiri. Susunan makanan yang tidak tepat pada kualitas dan kuantitas serta ketidakseimbangan antara konsumsi makanan dengan kebutuhan kalori yang dibutuhkan dapat menimbulkan masalah gizi. ${ }^{4}$ Masalah gizi ganda seperti gizi lebih dan gizi kurang merupakan masalah yang sering terjadi pada remaja. ${ }^{5}$ Terdapat berbagai faktor yang mempengaruhi status gizi pada remaja, antara lain yaitu asupan makan, aktivitas fisik, body image dan jenis kelamin. ${ }^{6}$

Banyak remaja di negara berkembang mengalami masalah gizi kurang yang menyebabkan remaja mengalami gangguan kesehatan. Sejumlah penelitian menunjukkan tingginya remaja stunting dan kurus di negara berkembang. ${ }^{7}$ Hal ini disebabkan oleh perilaku remaja, kualitas pangan yang buruk, dan adanya infeksi penyakit yang mengakibatkan status gizi rendah pada remaja. ${ }^{8}$ Oleh karena itu, pemantauan status gizi pada kelompok anak dan remaja menjadi hal yang penting dalam memantau kesehatan masyarakat. ${ }^{9}$

Berdasarkan data Riskesdas Nasional tahun 2018 Provinsi Jawa Timur menunjukkan bahwa prevalensi status gizi remaja usia 13-15 tahun dilihat dari TB/U (Tinggi badan menurut umur) diperoleh data sebesar $6,4 \%$ sangat pendek, $18,8 \%$ pendek, $74,8 \%$ normal, kemudian status gizi anak usia 13-15 tahun dilihat dari IMT/U (Indeks Massa Tubuh menurut umur) diperoleh data sebesar 1,5\% sangat kurus, $5,7 \%$ kurus, $73,5 \%$ normal, $13,3 \%$ gemuk, dan $6,0 \%$ obesitas. ${ }^{10}$

Dalam sistem pendidikan di pondok pesantren, terdapat pembelajaran yang menganjurkan para santrinya untuk bermukim di dalam pondok selama proses pembelajaran. Dengan demikian, para santri ini bermukim dan menjalani waktu makan di dalam pondok pesantren. Bagi pihak pondok pesantren, kondisi ini membutuhkan tanggung jawab yang besar untuk dapat memberikan makanan yang baik kepada santri agar pemenuhan gizinya bisa tercukupi dan proses pembelajaran bisa berjalan dengan baik. Asupan pemberian makanan sangat berkontribusi dalam proses perkembangan dan pertumbuhan anak. ${ }^{11}$ Terdapat studi yang menyebutkan bahwa asupan zat gizi siswa yang tinggal di asrama cenderung lebih rendah dibandingkan dengan siswa yang tidak asrama. ${ }^{12}$ Sebuah studi menghasilkan bahwa rata-rata zat gizi makro siswa yang tinggal di asrama maupun yang non asrama di MAN 1 Semarang rata-rata masih kurang. ${ }^{13}$

Dalam menyediakan bahan makanan di pondok pesantren, pada umumnya terbatas karena masalah biaya akibatnya menu makanan yang disediakan ada kemungkinan belum bisa memenuhi kebutuhan gizi santrinya. ${ }^{14}$ Dalam penerapannya, masih terdapat penyelanggaraan pelayanan makanan untuk santri yang belum memenuhi standar nilai gizi makanan, karena yang disediakan hanya memenuhi $70 \%$ dari kebutuhan total. ${ }^{15}$ Hasil studi lain menyebutkan bahwa rata-rata ketersediaan energi hanya sebesar 60,8\% sedangkan rata-rata ketersediaan zat gizi untuk normalnya sebesar $90-120 \%$ AKG. $^{16}$

Pondok Pesantren Al Hikmah merupakan salah satu pondok pesantren di Kecamatan Menganti dengan jumlah santri sebanyak 30 santri yang tinggal menetap dipesantren. Berdasarkan observasi awal belum pernah dilakukan pengkajian gizi pada penyelenggaraan makanannya dan terdapat beberapa santri yang mengalami gizi kurang. Sehingga, penting untuk dilakukan analisis ketersediaan energi 
dan protein makan sehari di Pondok Pesantren Al Hikmah.

\section{METODE}

Penelitian ini merupakan penelitian deskriptif dengan pendekatan potong lintang. Penelitian dilakukan di Pondok Pesantren Al Hikmah Kabupaten Gresik dengan waktu penelitian pada bulan Oktober sampai Januari 2020 .

Sumber data diperoleh dengan cara menimbang bahan makanan kemudian menghitung kandungan gizinya. Instrumen yang digunakan dalam pengumpulkan data adalah formulir food weighing (formulir penimbangan bahan makanan yang akan dikonsumsi bertujuan untuk mengukur kuantitas makanan).

Data yang diperoleh diolah menggunakan software analisis data. Analisis data dilakukan dengan teknik membandingkan jumlah ketersediaan energi dan protein dalam sehari dengan angka kecukupan energi dan protein di tingkat ketersediaan berdasarkan rekomendasi Widyakarya Nasional Pangan dan Gizi X. ${ }^{17}$ Penelitian ini telah mendapatkan persetujuan etik No.553/HRECC.FODM/XII/2020 dari Komite Etik Penelitian Kesehatan Fakultas Kedokteran Gigi, Universitas Airlangga Surabaya.

\section{HASIL}

Penelitian dilakukan dengan cara menimbang bahan makanan menjadi satu dan dilakukan pada saat makan pagi, siang dan malam selama 7 hari dengan pengumpulan data menggunakan formulir food weighing. Proses perhitungan zat gizi menggunakan aplikasi NutriSurvey. Berikut ini tabel hasil pengumpulan data selama 7 hari:

Tabel 1. Ketersediaan Energi dan Protein Makan Sehari di Pondok Pesantren Al Hikmah Gresik.

\begin{tabular}{ccc}
\hline Hari & \multicolumn{2}{c}{ Rata-rata Per santri Zat Gizi } \\
\cline { 2 - 3 } ke & Energi & Protein \\
\hline 1. & 1468,3 & 42,17 \\
2. & 1709,03 & 43,41 \\
3. & 1299,44 & 29,7 \\
4. & 1301,058 & 44,70 \\
5. & 1766,132 & 38,5 \\
6. & 1237,969 & 48,89 \\
7. & 1075,342 & 36,57 \\
\hline
\end{tabular}

Tabel 2. Tingkat Ketersediaan Energi dan Protein Di Pondok Pesantren Pesantren Al Hikmah Gresik.

\begin{tabular}{lcc}
\hline Hasil & $\begin{array}{c}\text { Energi } \\
\text { (kkal) }\end{array}$ & $\begin{array}{c}\text { Protein } \\
\text { (kkal) }\end{array}$ \\
\hline $\begin{array}{l}\text { Rata-rata } \\
\text { Ketersediaan }\end{array}$ & 1408,313 & 40,57 \\
$\begin{array}{l}\text { Standar } \\
\text { Ketersediaan } \\
\text { (WNPG 2012) }\end{array}$ & 2400 & 63 \\
$\begin{array}{l}\text { Tingkat } \\
\text { Ketersediaan }\end{array}$ & $58,68 \%$ & $64,40 \%$ \\
\hline
\end{tabular}

Berdasarkan Tabel 2 dapat dilihat bahwa rata-rata ketersediaan energi dan protein makan sehari untuk santri yang tinggal di asrama Pondok Pesantren Al Hikmah Gresik adalah energi 1408,313 kkal dan protein 40,57gram. Berdasarkan WNPG 2012 standar kecukupan energi dan protein ditingkat ketersediaan adalah 2400 kkal dan protein 63 gram sehingga diperoleh tingkat ketersediaan untuk energi $58,68 \%$ dan protein $64,40 \%$.

\section{PEMBAHASAN}

Ketersediaan makanan pondok pesantren adalah makanan yang disiapkan dan disajikan setiap harinya untuk sarapan, makan siang dan makan malam oleh pondok pesantren. Tingkat ketersediaan zat gizi terutama energi dan protein dalam penyelenggaraan makanan pondok pesantren menjadi indikator penting dalam mengetahui kemampuan penyelenggaraan makanan di pondok pesantren. Ketersediaan energi dan protein dapat diketahui dengan melihat ratarata kandungan gizi bahan makanan yang disajikan selama 7 hari. Berikut ini pembahasan ketersediaan energi dan ketersediaan protein:

\section{Ketersediaan Energi}

Bahan makanan sumber energi yang digunakan di Pondok Pesantren Al Hikmah yaitu beras dan mie. Ketersediaan energi tertinggi ada pada hari kelima yaitu sebesar 1766,132 kkal dengan menu nasi, lele goreng, papaya, sayur asem, pindang goreng, tahu, telur dan terendah ada pada hari ketujuh yaitu sebesar 1075,342 kkal dengan menu nasi putih, nasi goreng, telur dadar, sayur sop, mie kuah. Ketersediaan energi tertinggi pada hari kelima disebabkan karena pada hari tersebut sumber 
energi yang disediakan lebih banyak dari biasanya dan pengolahan makannya hampir semuanya digoreng.

Dalam penyelenggaraan makanan selama 7 hari didapatkan rata-rata ketersediaan energi sebesar 1408,313 kkal/org/hari sehingga persentase tingkat ketersediaan energi 58,68\%. Berdasarkan hal tersebut maka dapat diketahui bahwa ketersediaan energi di Pondok Pesantren Al Hikmah masih dibawah dari standar rata-rata konsumsi di tingkat ketersediaan. Ketersediaan energi yang kurang seringkali dapat menyebabkan berbagai masalah gizi seperti status gizi kurang. Sebuah penelitian menunjukkan adanya hubungan bermakna antara ketersediaan pangan dengan kejadian gizi kurang dan gizi buruk pada balita yang tinggal di sekitar Puskesmas Beruntung Raya. ${ }^{18}$

Penelitian ini sejalan dengan penelitian Rukmin L dan Suranadi L di Pondok Pesantren Nurul Hakim Kediri Kabupaten Lombok Barat bahwa ketersediaan energi hanya sebesar $64,1 \%$ dari AKG. ${ }^{19}$ Penelitian ini juga sejalan dengan penelitian Sudrajat dan Tiurma di Pondok Pesantren Darul Arqam Garut bahwa ketersediaan energi hanya sebesar $60,8 \%$ dari AKG. ${ }^{16}$

\section{Ketersediaan Protein}

Bahan makanan sumber protein yang digunakan di Pondok Pesantren Al Hikmah yaitu terdiri dari tahu, tempe, ayam, daging sapi dan telur. Selanjutnya ketersediaan protein yang disediakan Pondok Pesantren Al Hikmah tertinggi ada pada hari keenam yaitu sebesar 48,899gram dengan menu nasi putih oseng tempe, telur dadar, tempe bumbu kuning, lodeh daging sapi, tahu, tempe serta mie kuah dan terendah ada pada hari ketiga yaitu sebesar 29,721 gram dengan menu nasi gulai kambing, tahu petis, tahu goreng, dan perkedel jagung. Ketersediaan protein tertinggi pada hari keenam disebabkan karena pada hari tersebut sumber protein yang disediakan ada beragam bahan makanan yang tinggi protein seperti tempe, telur, daging sapi. Berbeda dengan hari ketiga hanya daging kambing saja.

Dalam penyelenggaraan makanan selama 7 hari didapatkan rata-rata ketersediaan protein makan sehari untuk santri yang tinggal di asrama Pondok Pesantren Al Hikmah Gresik adalah sebesar 40,57 gram/org/hari, sehingga diperoleh persentase ketersediaan protein $64,40 \%$. Berdasarkan hal tersebut maka dapat diketahui bahwa ketersediaan protein di Pondok Pesantren Al Hikmah masih dibawah dari standar rata-rata konsumsi di tingkat ketersediaan. Penelitian ini sejalan dengan penelitian Rukmin L dan Suranadi L di Pondok Pesantren Nurul Hakim Kediri Kabupaten Lombok Barat bahwa ketersediaan protein hanya sebesar $54,0 \%$ dari AKG. ${ }^{19}$ Penelitian ini juga sejalan dengan penelitian Sudrajat dan Tiurma di Pondok Pesantren Darul Arqam Garut bahwa ketersediaan protein hanya sebesar 50,9\% dari AKG. ${ }^{16}$

Sebuah penelitian di Pondok Pesantren

Putri Ummul Mukminin Makassar menunjukkan bahwa nilai gizi makanan terutama energi hanya mencapai sekitar 50\% dari kebutuhan total santri walaupun untuk mutu makanan dapat diterima. ${ }^{20}$ Kecukupan energi ini sangat berpengaruh terhadap peningkatan daya terima dan daya ingat ketika belajar. ${ }^{21}$

Ketersediaan energi dan protein yang kurang akan memberi dampak negatif bagi pertumbuhan dan keadaan gizi santri remaja. Adapun masalah gizi yang seringkali dialami oleh remaja salah satunya adalah gizi kurang. Gizi kurang adalah ketika jumlah asupan energi dan zat gizi lainnya tidak dapat memenuhi kebutuhan tubuh. ${ }^{22}$ Adanya masalah gizi kurang pada remaja ini diantaranya disebabkan oleh kemiskinan, kurangnya persediaan pangan, kurang baiknya kualitas lingkungan, dan kurangnya pengetahuan masyarakat tentang gizi. ${ }^{23}$ Kondisi kurang gizi yang terjadi pada remaja akan memberikan dampak buruk terhadap kondisi kesehatan fisik, mental, intelektual dan sosial remaja. ${ }^{24}$ Makanan sangat berhubungan terhadap kebutuhan tubuh anak, terutama untuk anak sekolah yang sedang mengalami fase pertumbuhan dan perkembangan fisik serta kecerdasan. Bila makanan kurang mengandung zat-zat gizi yang dibutuhkan, dan kondisi ini berlangsung lama, dapat menyebabkan perubahan metabolisme dalam otak sehingga berakibat terjadinya ketidakmampuan otak berfungsi secara normal. ${ }^{25}$ Kekurangan gizi dapat menimbulkan berbagai keterbatasan, diantaranya yaitu laju pertumbuhan anak yang mendatar (growth faltering), serta berat dan tinggi badan menyimpang dari pertumbuhan normal. Kondisi kurang gizi tidak hanya berhubungan dengan pertumbuhan fisik, tetapi juga berasosiasi dengan perkembangan motorik dan kognitif. ${ }^{26}$ Selain itu, terdapat 
penelitian bahwa semakin tinggi remaja yang memiliki status gizi kurang maka semakin tinggi pula angka kejadian anemia pada remaja putri. $^{27}$ Pada dasarnya masalah gizi yang terjadi pada remaja juga dipengaruhi oleh kekurangan gizi sejak dilahirkan. Status gizi yang buruk pada masa bayi berkorelasi dengan pertumbuhan di masa remaja. ${ }^{28}$

Ketersediaan zat gizi yang cukup adalah suatu hal yang penting dalam mempersiapkan kebutuhan zat gizi individu terutama remaja, dalam hal ini adalah santri Pondok Pesantren Al Hikmah. Salah satu masalah yang dihadapi oleh pihak pondok adalah sebagian besar bahan makanan berasal dari donatur, sehingga apabila terjadi keterlambatan akan berpengaruh pada penyelenggaraan makanannya. Untuk itu perlu ada manajemen pengadaan dan penyimpanan bahan makanan di dalam pondok pesantren, sehingga kebutuhan harian santri selalu dapat tercukupi. Penelitian Afrizal et al (2017) menyebutkan kekurangan pangan dapat mempengaruhi status gizi suatu keluarga. ${ }^{29}$ Sehingga penting bagi pengelola pondok pesantren untuk bisa menyediakan makanan yang sesuai dengan kebutuhan santri, sehingga kesehatan santri dapat terjaga.

\section{KESIMPULAN}

Berdasarkan hasil analisis yang telah dilakukan oleh peneliti, dapat ditarik kesimpulan bahwa ketersediaan energi di Pondok Pesantren Al Hikmah masih dibawah dari standar rata-rata konsumsi di tingkat ketersediaan yaitu sebesar 1408,313 $\mathrm{kkal} /$ org/hari $(58,68 \%)$. Begitu pula dengan ketersediaan protein di Pondok Pesantren Al Hikmah juga masih dibawah dari standar ratarata konsumsi di tingkat ketersediaan yaitu sebesar 40,57 gram/org/hari (64,40\%).

\section{SARAN}

Saran yang dapat diberikan oleh peneliti untuk pihak penyelenggara pelayanan makanan di Pondok Pesantren Al Hikmah adalah untuk dapat meningkatkan ketersediaaan energi dan protein sesuai kebutuhan santri yang tinggal di pondok pesantren berdasarkan AKG 2019. Dalam pengadaan bahan makanan, penting untuk dapat menyediakan bahan makanan yang beragam, bergizi, seimbang dan aman. Dengan demikian, pentingnya terdapat manajemen penyelenggaraan pelayanan makanan yang baik untuk mencukupi kebutuhan harian para santri. Dan pada peneliti selanjutnya dapat melakukan penelitian tentang tingkat penerimaan makanan dan tingkat asupan makanan santri di pondok pesantren.

\section{DAFTAR PUSTAKA}

1. Shahid A, Siddiqui, FR, Bhatti, MA, Ahmed M KM. Assesment of Nutrition Status of Adolescent College Girls at Rawalpindi Annals. 2009;15:11-6.

2. Susetyowati. Gizi Remaja. Buku Kedokteran EGC; 2014.

3. Pamela S H. Gizi Normal Pada Remaja. Jakarta: Buku Kedokteran EGC; 2014.

4. Almatsier S. Prinsip Dasar Ilmu Gizi. Jakarta: Buku Kedokteran EGC; 2010.

5. Khomsan A. Pangan dan Gizi Untuk Kesehatan. Jakarta: PT Raja Grafindo Persada; 2010.

6. Rusli, R H, Darmadi. Analisis Regresi Logistik Untuk Faktor-Faktor Yang Mempengaruhi Status Gizi Remaja. J Maj Kedokt Andalas. 2012;36(1):62-72.

7. Arage G, Assefa M, Worku T. SocioDemographic And Economic Factors Are Associated With Nutritional Status Of Adolescent School Gilrs in Lay Guyint Woreda, Northwest Ethiopia. J Sage. 2019;(7):1-10.

8. Briawan D. Anemia Masalah Gizi Pada Remaja Wanita. Jakarta: Buku Kedokteran EGC; 2014.

9. Oninla S, Owa J, Onayade, A A, Taiwo O. Comparative Study Of Nutritional Status Of Urban And Rural Nigerian School Children. J Trop Pediatr. 2007;53(1):39-43.

10. Riskesdas Nasional Provinsi Jawa Timur. Prevalensi Status Gizi Remaja. 2018.

11. Adyas A, Dika, Karbito. BBLR diprediksi Faktor Utama Kejadian Stunting di Provinsi Lampung: Warning untuk Ibu Bekerja dan Penerapan Pola Asuh. J Ilm Kesehat Masy. 2019;11(4):325-35.

12. Luo R, Shi Y, Zhang L, Liu C, Rozelle S, Sharbono B. Malnutrition in China's rural boarding schools: the case of primary schools in Shaanxi Province. J Asia Pacific Educ. 2009;29(4):481-501.

13. Amalia S. Tingkat Konsumsi Makanan Zat Gizi Makro Pada Siswa Yang Tinggal Di Asrama dan Non Asrama Di 
MAN 1 Semarang. J Nutr. 2018;

14. Alaofe H, Zee J, Dossa R, O'brien H. Effect of A Nutrition Education Program and Diet Modification In Beninese Adolescent Girls Suffering From Mild Iron Deficiency Anemia. J Ecol Food Nutr. 2009;48(1):21-38.

15. Taqhi A. Gambaran Sistem Penyelenggaraan Makanan Di Pondok Pesantren Hubulo Gorontalo. J Media Kesehat Masy Indones. 2014;241-7.

16. Sudrajat, A S, Tiurma S. Analisis Biaya Makan Terhadap Ketersediaan Makanan Serta Tingkat Kecukupan Gizi Santri Di Pondok Pesantren Darul Arqam Garut. J Indones Nutr Assoc. 2016;39(2):115-24.

17. Menteri Kesehatan RI. Angka Kecukupan Gizi : Permenkes RI No 75 Tahun 2013 tentang Angka Kecukupan Gizi yang Dianjurkan bagi Bangsa Indonesia. Jakarta; 2013.

18. Rahma R, Arifin S, Hayatie L. Hubungan Ketersediaan Pangan dan Penghasilan Keluarga Dengan Kejadian Gizi Kurang dan Gizi Buruk Pada Balita Di Wilayah Kerja Puskesmas Beruntung Raya. Homeostatis J Mhs Pendidik Dr. 2020;3(3):401-6.

19. Rukmin L, Suranadi L. Ketersediaan Zat Gizi Siswi di Yayasan Pondok Pesantren Nurul Hakim Kediri Kabupaten Lombok Barat. J Prime Nutr. 2016;1(1):1-8.

20. Ilmi N, Djunaidi, Dachlan M, Yustini. Gambaran Sistem Penyelenggaraan Makanan di Pondok Pesantren Putri Ummul Mukminin Makassar. J Univ Hasanuddin Makassar. 2014;

21. Nursyafitri, Sirajuddin, Tamrin A. Kebiasaan Sarapan dan Kemampuan Menghafal Al-Quran di Pondok Pesantren Moderen Ulul Albab Kelurahan Sudiang Raya Kecamatan
Biringkanaya Kota Makassar. J Media Gizi Pangan. 2014;18(2).

22. Andriani M, Wirjatmadi B. Peranan Gizi dalam Siklus Kehidupan. Jakarta: Kencana Prenada Media Group; 2012.

23. Reppi B, Kapantow NH, Punuh MI. Hubungan Antara Asupan Energi dengan Status Gizi Siswi SMA Negeri 4 Manado. J KESMAS Univ Sam Ratulangi. 3(1).

24. Zahtamal, Munir S. Edukasi Kesehatan Tentang Pola Makan dan Latihan Fisik Untuk Pengelolaan Remaja Underweight. J PKM Pengabdi Kpd Masy. 2019;2(1):64-70.

25. Pamularsih A. Hubungan Status Gizi dengan Prestasi Belajar Siswa Di Sekolah Dasar Negeri 2 Selo Kecamatan Selo Kabupaten Boyolali. Universitas Muhammadiyah Surakarta; 2009.

26. Anwar F, Briawan D, Rahayu WP, Sumiati, Purwaningsih S, Santoso J, et al. Pangan dan Gizi untuk Kesehatan dan Kesejahteraan Masyarakat. Bogor: IPB Press; 2018.

27. Hapzah, Ramlah Y. Hubungan Tingkat Pengetahuan Dan Status Gizi Terhadap Kejadian Anemia Remaja Putri Pada Siswi Kelas III Di SMAN 1 Tinambung Kabupaten Polewali Mandar. J Media Gizi Pangan. 2012;8(1):20-5.

28. Pangow S, Bodhi W, Budiarso F. Status Gizi pada Remaja SMP Negeri 6 Manado Menggunakan Indeks Massa Tubuh dan Lingkar Pinggang. J Biomedik. 12(1):43-7.

29. Arlius A, Sudargo T, Subejo. Hubungan Ketahanan Pangan Keluarga Dengan Status Gizi Balita (Studi Di Desa Palasari Dan Puskesmas Kecamatan Legok, Kabupaten Tangerang). J Ketahanan Nas. 2017;23(3):359-75. 